\title{
抗がん薬に伴う末梢神経障害に対するミロガバリンの有効性評価
}

\author{
石川雄大 ${ }^{* 1}$, 高木昭佳 ${ }^{1}$, 梶浦新也 ${ }^{2}$, 真鍋優希子 ${ }^{3}$, 高橋則正 ${ }^{1}$, 小野敦央 ${ }^{1}$, 加藤 敦 $^{1}$ \\ 富山大学附属病院薬剂部 ${ }^{1}$, 臨床腫瘍部 ${ }^{2}$, 麻酔科学講座 $^{3}$
}

\section{Efficacy Evaluation of Mirogabalin for Chemotherapy-induced Peripheral Neuropathy}

\author{
Yudai Ishikawa* ${ }^{* 1}$, Akiyoshi Takaki', Shinya Kajiuraª, \\ Yukiko Manabe ${ }^{3}$, NorimasaTakahashi ${ }^{1}$, Atsuo Ono ${ }^{1}$ and Atsushi Kato \\ Department of Pharmacy ${ }^{1}$, Department of Clinical Oncology ${ }^{2}$, \\ Department of Anesthesiology ${ }^{3}$, Toyama University Hospital \\ $\left[\begin{array}{l}\text { Received July 29, } 2020 \\ \text { Accepted October 16, } 2020\end{array}\right]$
}

\begin{abstract}
Chemotherapy-induced peripheral neuropathy (CIPN) reduces patient quality of life, but there is little evidence of preexisting supportive care drugs. Mirogabalin is a novel drug with indications for peripheral neuropathic pain, and its mechanism of action involves strong and selective binding to the voltage-gated calcium channel $\alpha 2 \delta$ subunit. We examined the effects of mirogabalin on CIPN. We followed up 21 patients with CIPN caused by taxanes or platinum-based anticancer drugs who started mirogabalin. A numerical rating scale (NRS) was used for the evaluation, and pharmacists evaluated the mirogabalin dose at its initiation by creatinine clearance in all patients, and no overdoses occurred. Mirogabalin significantly reduced NRS scores from a median of 6 to $2(P<0.001)$, and the median number of days of mirogabalin administration until determination of the best effect was 29.5 days. Furthermore, the median NRS significantly decreased by administration of mirogabalin in both the taxanes-based anticancer drug group and the platinum-based anticancer drug group. In the safety investigation, a somnolence grade of 1 or 2 was observed in 4 patients, an edema grade of 1 or 2 in 4 patients, and an edema grade of 3 was observed in 1 patient. There were no serious side effects that required hospitalization. Our study suggests mirogabalin has a palliative effect on CIPN and may be an important supportive care drug for chemotherapy. Simultaneously, it's considered that pharmacists evaluate renal function and contribute to proper use, so that patients can expect the maximum drug efficacy after the introduction of mirogabalin.
\end{abstract}

Key words — chemotherapy, peripheral neuropathy, mirogabalin, numerical rating scale, supportive care

\section{緒 言}

近年, 新規抗がん薬の登場や, 既存抗がん薬の 併用治療の発展に伴い, 多種多様な副作用マネジ メントの重要性が高まっている。支持療法では, 腫瘍崩壊症候群に対するラスブリカーゼ ${ }^{1)}$ や制吐 剂としてのオランザピン, ${ }^{2}$ 発熱性好中球減少症 の発症抑制におけるぺグフィルグラスチム ${ }^{3)}$ など 進歩が見られる。一方，抗がん薬に伴う末梢神経 障害 (chemotherapy-induced peripheral neuropathy:
CIPN）では, 既存薬剤の効果がそしく, 課題の 多い領域である. CIPN の出現は予後と相関しな いとはされるが, ${ }^{4}$ 症状の増悪が治療の中断や社 会生活への支障を引き起こしたり，身体面と精神 面から患者の生活の質を低下させたりする要因と

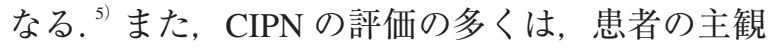
性に沿ったものであるため，その評価が難しい。 CIPN は様々な抗がん薬によって生じるが，その 発生機序は病理組織学的に, 軸索障害, 神経細胞 体障害, 髄鞘障害に分類される. ${ }^{7}$ パクリタキセ

\footnotetext{
*テ930-0194＼cjkstart富山市杉谷2630
} 
ルなどのタキサン系抗がん薬は, 微小管阻害作用 によって，四肢遠位部位優位の手袋 - 靴下型の感 覚異常を引き起こす。 ${ }^{8}$ 転移性乳がんの治療にお いて，パクリタキセルの毎週投与と 3 週投与を比 較した臨床試験では，毎週投与の方が 3 週投与よ り治療成績が良かった一方で, 重篤な神経障害の

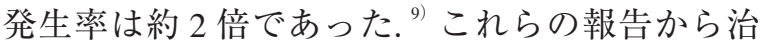
療効果を最大限，かつ副作用を最小限にするため にCIPN の副作用マネジメントは重要と考えられ る.オキサリプラチンなどのプラチナ系抗がん薬 は, 病変主座が後根神経節の神経細胞体障害のた め, 慢性的な感覚障害を引き起こし, ${ }^{8}$ 回復が遅く, 症状が数力月から数年続く場合もある. ${ }^{10}$

しかし，CIPN の治療法は未だ確立されていな い. 支持薬として一般的に知られるデュロキセチ ンでは, 米国臨床腫瘍学会専門委員会によるシス テマティックレビュー ${ }^{11}$ で，その有効性は中等度 の推奨となっている. 日本がんサポーティブケア 学会より発刊されている「がん薬物療法に伴う末 梢神経障害マネジメントの手引き 2017 年版」12 では，国内外の検証 ${ }^{13,14)}$ から，デュロキセチンは 弱い推奨となっている，問題点としては，添付文 書（サインバルタ®添付文書, 日本イーライリリー 株式会社，2020 年 2 月改定第 2 版）上，使用で きる疼痛が線維筋痛症, 慢性腰痛症, 変形性関節 症に伴う場合のみのため, CIPN に関しては保険 適応を有していない。また, 安全性では, 消化器 症状が最も多い副作用である。

ミロガバリンの類薬であるプレガバリンでは, $\mathrm{CIPN}$ への有効性を見たランダム化比較試験は存 在せず，症例報告があるのみである. ${ }^{15}$ 適応とし ては，添付文書（リリカ®添付文書，ファイザー 株式会社, 2019 年 11 月改定第 1 版）上, 神経障 害性疼痛に使用できるが, 安全性ではインタ ビューフォーム（リリカ®インタビューフォーム, ファイザー株式会社，2020 年 1 月改定第 13 版） 記載の糖尿病性末梢神経障害に伴う疼痛における プレガバリンの国内長期投与試験では, 副作用と して傾眠やめまいが多く報告されている.

漢方薬の牛車腎気丸は，オキサリプラチン CIPN の症状緩和予防に期待されたが，大規模なランダ ム化比較試験で有効性を示すことができなかっ
た. ${ }^{16)}$ ま，药薬甘草湯を服用することで, modified FOLFOX6 療法に打ける CIPN の発現頻度が低下し たとの報告 ${ }^{17)}$ や，パクリタキセルを含む治療から生 じた末梢神経障害が改善したとの報告 ${ }^{18)}$ があるが, 安全性の面では, 内服 1 日量で甘草（グリチルリチ ンが主成分）が $6.0 \mathrm{~g}$ 入っており, 長期服用による

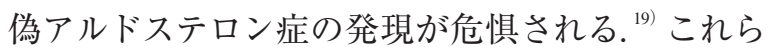
の支持薬を使用しない場合, 一般的には抗がん薬 の減量または中止・休薬が CIPN の対処法となる.

ミロガバリンは, 末梢性神経障害性疼痛に保険 適応を有す新規薬剤である。作用機序は, 電位依 存性カルシウムチャネル $\alpha_{2} \delta$ サブユニットに対す る強力かつ相対選択的な結合を示す. ${ }^{20)}$ ミロガバ リンは糖尿病性末梢神経障害性疼痛 ${ }^{21)}$ と带状疮 疹後神経痛 ${ }^{22)}$ を有する患者に対して実施された 試験結果に基づき承認を受けたが，CIPNを有す る患者にも有効である可能性がある. CIPN 領域 に扔ける効果的支持薬の確立は, 患者の生活の質 向上に必須であると考える。しかし，CIPN に対 するミロガバリンの効果や安全性を調べた論文報 告はない，今回我々は CIPN に対するミロガバリ ンの有効性を検討したので報告する.

\section{方 法}

\section{1. 対象}

ミロガバリンが院内採用となった 2019 年 4 月 15 日〜2019 年 10 月 31 日の間で, 富山大学附属病 院に扮いて，治療レジメンを限定せず，医師が CIPN に対して処方が必要と判断し，ミロガバリン が新規導入され，その当日から薬殽師が numerical rating scale（NRS）による評価を行えた患者 21 名 を対象とした。

\section{2. 調査方法}

CIPN に対し，ミロガバリンが導入された患者 を追跡調查した，疼痛の評価は NRS を用いて患 者に回答してもらい，ミロガバリンの導入前後で 比較した. ミロガバリンの導入後, NRS が低下し た場合, 最も低下した際の NRS を把握するのに要 した日数を, 最良効果判定期間とした. なお, 本文 中におけるクレアチニンクリアランス（creatinine 
clearance: $\mathrm{CCr}$ ）の算出には, Cockcroft-Gault 式を 用いた。 また，卵巣がんに対してパクリタキセル＋ カルボプラチン療法を施行されていた患者に関し ては, 両薬剤が被疑薬であるので, 夕キサン系抗 がん薬群とプラチナ系抗がん薬群のそれぞれに加 えて, デー夕解析を行った。 ミロガバリンの副作用 については, Common terminology criteria for adverse events version 5.0 (CTCAE ver.5)を用いて評価した.

\section{3. 統計}

ミロガバリン導入前後における NRS を関連の ある 2 群とし，順序データの有意性をウィルコク ソンの符号付順位和検定を用いて検討した. $P<$ 0.05 の場合, 統計学的有意差ありとした。なお,
統計解析には, Statcel 4 ((有)オーエムエス出版, 東京）を用いた。

\section{4. 倫理的配慮}

本研究は「人を対象とする医学系研究に関する 倫理指針」を遵守し, 当院の倫理審査委員会の承 認（臨 28-138）を得て実施した。

\section{結 果}

\section{1. 患者背景}

本研究の患者背景を表 1 に示す，年齢の中央値 は 68 歳で, 男性の患者割合が多かった。対象疾 患としては, 膵臟がんが最も多く, 対象レジメン

表 1 ミロガバリン導入時患者背景

\begin{tabular}{|c|c|c|}
\hline 調査項目 & $(\mathrm{n}=21)$ & \\
\hline 年齢中央値（歳） & 68 & $(47-87)$ \\
\hline 性別（男性 / 女性） & $13 / 8$ & \\
\hline クレアチニンクリアランス $(\mathrm{mL} / \mathrm{min})$ & 75.8 & $(36.3-136.3)$ \\
\hline \multicolumn{3}{|l|}{ 対象疾患 } \\
\hline 膵臓がん & 17 & \\
\hline 大腸がん & 2 & \\
\hline 卵巣がん & 1 & \\
\hline 胃がん & 1 & \\
\hline \multicolumn{3}{|l|}{ 治療レジメン } \\
\hline Gemcitabine + nab-Paclitaxel & 12 & \\
\hline modified FOLFIRINOX & 5 & \\
\hline Dose-dense Paclitacel + Carboplatin & 1 & \\
\hline modified FOLFOX6 & 1 & \\
\hline CapeOX & 1 & \\
\hline FOLFOXIRI & 1 & \\
\hline \multicolumn{3}{|l|}{ 神経障害起因薬剤総投与量 $\left(\mathrm{mg} / \mathrm{m}^{2}\right)$} \\
\hline カルボプラチン $(\mathrm{n}=1)$ & 531.1 & \\
\hline オキサリプラチン $(\mathrm{n}=8)$ & 882.3 & $(509-1,324.1)$ \\
\hline パクリタキセル（n=1） & $1,580.9$ & \\
\hline ナブパクリタキセル $(\mathrm{n}=12)$ & $1,245.5$ & $(499.1-3,450.9)$ \\
\hline 最良効果判定までのミロガバリン投与日数（日） & 29.5 & $(7-77)$ \\
\hline \multicolumn{3}{|l|}{ 併用薬剂（重複あり） } \\
\hline \multicolumn{3}{|l|}{ セロトニン・ノルアドレナリン再取り込み阻害薬 } \\
\hline $\begin{array}{l}\text { デュロキセチンカプセル } \\
\text { オピオイド鎮痛薬 }\end{array}$ & 3 & \\
\hline フェンタニルクエン酸塩 1 日用テープ & 1 & \\
\hline モルヒネ塩酸塩錠 & 1 & \\
\hline トラマドール塩酸塩口腔内崩壊錠 & 1 & \\
\hline \multicolumn{3}{|l|}{ 非ステロイド性消炎鎮痛薬 } \\
\hline セレコキシブ錠 & 2 & \\
\hline \multicolumn{3}{|l|}{ 漢方薬 } \\
\hline 牛車腎気丸エキス顆粒 & 2 & \\
\hline \multicolumn{3}{|l|}{ ステロイド } \\
\hline デキサメタゾン錠 & 1 & \\
\hline
\end{tabular}


としても膵蔵がんで使用されるゲムシタビン + ナブパクリタキセル療法（GNP療法）が最多で あった.ミロガバリンが導入された時点での神経 障害起因の薬剂総投与量中央值は, カルボプラチ ンが $531.1 \mathrm{mg} / \mathrm{m}^{2}$, オキサリプラチンが $882.3 \mathrm{mg} / \mathrm{m}^{2}$, パクリタキセルが $1,580.9 \mathrm{mg} / \mathrm{m}^{2}$, ナブパクリタ キセルが $1,245.5 \mathrm{mg} / \mathrm{m}^{2}$ であった。 また，ミロガ バリンの最良効果判定までの投与日数中央值は, 29.5 日であった.ミロガバリン内服期間に患者が 併用していた薬剤の種類には, セロトニン・ノル アドレナリン再取り込み阻害薬, オピオイド鎮痛 薬, 非ステロイド性消炎鎮痛薬, 漢方薬, ステロ イドがあった，表 2 に本研究追跡期間中の併用薬 の投与量や，その用量変更について詳細を示す. 併用薬はすべてミロガバリン処方開始時から使用
されており，追跡期間中の増量はなかった.

ミロガバリン導入時の $\mathrm{CCr}$ 中央值は, $75.8 \mathrm{~mL} /$ min であった. ミロガバリン導入時の患者集団に おける腎機能と, ミロガバリン投与量を図 1 に示 す. CCrが $60 \mathrm{~mL} / \mathrm{min}$ 以上の患者におけるミロガ バリン開始用量は $10 \mathrm{mg} /$ day, $\mathrm{CCr}$ が $60 \mathrm{~mL} / \mathrm{min}$ 未満, $30 \mathrm{~mL} / \mathrm{min}$ 以上の患者におけるミロガバリ ン開始用量は $5 \mathrm{mg} /$ day $と$, 過量投与なく適正な 投与量となっていた.

\section{CIPN に対するミロガバリンの有効性}

患者 21 名のミロガバリン導入前と導入後（最 良効果判定日）における NRS の変化を図 2A に示 す.ミロガバリン導入前の CIPN による NRS は, 中央值 6 であったが, ミロガバリン導入後の NRS

表 2 症例別ミロガバリンの投与量と NRS の変化

\begin{tabular}{|c|c|c|c|c|c|c|c|c|c|c|c|c|}
\hline \multirow[b]{2}{*}{$\begin{array}{l}\text { 症例 } \\
\text { 番号 }\end{array}$} & \multirow[b]{2}{*}{ 性別 } & \multirow[b]{2}{*}{$\begin{array}{l}\text { 年齢 } \\
\text { (歳) }\end{array}$} & \multirow[b]{2}{*}{$\begin{array}{c}\mathrm{CCr} \\
(\mathrm{mL} / \mathrm{min})\end{array}$} & \multirow[b]{2}{*}{$\begin{array}{c}\text { 治療 } \\
\text { レジメン }\end{array}$} & \multirow[b]{2}{*}{$\begin{array}{c}\text { ミロガバリン } \\
\text { 投与量 } \\
(\mathrm{mg} / \mathrm{day})\end{array}$} & \multirow[b]{2}{*}{$\begin{array}{c}\text { 最良効果 } \\
\text { 判定期間 } \\
\text { (日) }\end{array}$} & \multirow[b]{2}{*}{$\begin{array}{l}\text { 改善 } \\
\text { 有無 }\end{array}$} & \multicolumn{2}{|c|}{ NRS } & \multicolumn{3}{|c|}{ 追跡期間中 } \\
\hline & & & & & & & & 投与前 & 投与後 & 併用薬 & $\begin{array}{c}\text { 併用薬 } \\
\text { 投与量 } \\
(\mathrm{mg} / \text { day })\end{array}$ & $\begin{array}{c}\text { 併用薬投与量 } \\
\text { 変更 }\end{array}$ \\
\hline 1 & 男 & 57 & 89.7 & mFOLFOX6 & 10 & 14 & あり & 3 & 0 & $\begin{array}{c}\text { フェンタニル } \\
\text { クェン酸塩 } \\
1 \text { 日用テープ }\end{array}$ & 3 & 継続 \\
\hline 2 & 女 & 60 & 80.7 & GNP & 10 & 31 & あり & 4 & 0 & - & - & - \\
\hline 3 & 男 & 47 & 121.4 & CapeOX & 10 & 49 & あり & 6 & 0 & - & - & - \\
\hline 4 & 男 & 71 & 63.9 & FOLFOXIRI & 10 & 63 & あり & 7 & 0 & - & - & - \\
\hline 5 & 男 & 68 & 114.3 & GNP & 10 & 15 & あり & 8 & 7 & セレコキシブ錠 & 400 & 継続 \\
\hline 6 & 女 & 83 & 64.1 & GNP & 10 & 70 & あり & 8 & 3 & - & - & - \\
\hline 7 & 男 & 73 & 64.3 & mFFX & 10 & - & $\begin{array}{c}\text { なし } \\
\text { (追跡不能) }\end{array}$ & 10 & 10 & - & - & - \\
\hline 8 & 女 & 64 & 58.8 & ddTC & $5 \rightarrow 10$ & 14 & あり & 2 & 0 & - & - & - \\
\hline 9 & 男 & 79 & 36.3 & GNP & $5 \rightarrow 10$ & 28 & あり & 10 & 5 & $\begin{array}{c}\text { デュロキセチン } \\
\text { カプセル }\end{array}$ & 20 & 継続 \\
\hline 10 & 男 & 87 & 46.5 & GNP & $5 \rightarrow 10$ & 7 & あり & 5 & 3 & - & - & - \\
\hline 11 & 女 & 70 & 75.8 & GNP & $5 \rightarrow 10$ & 14 & あり & 6 & 3 & - & - & - \\
\hline 12 & 男 & 67 & 77.2 & GNP & $10 \rightarrow 20$ & 28 & あり & 3 & 1 & - & - & - \\
\hline 13 & 男 & 58 & 83.2 & GNP & $10 \rightarrow 20$ & 28 & あり & 5 & 0 & セレコキシブ錠 & 200 & 継続 \\
\hline 14 & 男 & 63 & 125.7 & GNP & $10 \rightarrow 20$ & 43 & あり & 7 & 5 & - & - & - \\
\hline 15 & 男 & 61 & 105.7 & GNP & $10 \rightarrow 20$ & 13 & あり & 10 & 8 & $\begin{array}{l}\text { 牛車腎気丸エキス } \\
\text { 顆粒, デュロキ } \\
\text { セチンカプセル }\end{array}$ & $7.5,40$ & 継続 \\
\hline 16 & 男 & 52 & 117.3 & mFFX & $10 \rightarrow 20$ & - & $\begin{array}{c}\text { なし } \\
\text { (追跡不能) }\end{array}$ & 3 & 3 & $\begin{array}{c}\text { 牛車腎気丸エキス } \\
\text { 顆粒 }\end{array}$ & 7.5 & 継続 \\
\hline 17 & 女 & 52 & 136.3 & mFFX & $10 \rightarrow 20$ & - & なし & 7 & 7 & $\begin{array}{l}\text { デキサメタゾン錠, } \\
\text { モルヒネ塩酸塩錠 }\end{array}$ & $\begin{array}{c}60 \\
8 \rightarrow 4\end{array}$ & $\begin{array}{c}\text { デキサメタゾン錠 } \\
\text { のみ追跡開始 } \\
32 \text { 日目に減量 }\end{array}$ \\
\hline 18 & 女 & 72 & 58.3 & mFFX & $5 \rightarrow 10 \rightarrow 15$ & 42 & あり & 7 & 2 & $\begin{array}{c}\text { デュロキセチン } \\
\text { カプセル }\end{array}$ & 20 & 継続 \\
\hline 19 & 女 & 76 & 61.3 & GNP & $5 \rightarrow 10 \rightarrow 15$ & 77 & あり & 5 & 1 & - & - & - \\
\hline 20 & 女 & 71 & 63.8 & GNP & $10 \rightarrow 20 \rightarrow 30$ & 56 & あり & 3 & 0 & $\begin{array}{l}\text { トラマドール } \\
\text { 塩酸塩 } \\
\text { 口腔内崩壊錠 }\end{array}$ & $150 \rightarrow 100$ & $\begin{array}{c}\text { 追跡開始 } \\
29 \text { 日目に減量 }\end{array}$ \\
\hline 21 & 男 & 70 & 75.0 & mFFX & $10 \rightarrow 20 \rightarrow 30$ & 42 & あり & 5 & 0 & - & - & - \\
\hline
\end{tabular}

numerical rating scale: NRS, creatinine clearance: CCr, modified FOLFOX6: mFOLFOX6, Dose-dense Paclitacel + Carboplatin: ddTC, gemcitabine + nabPaclitaxel: GNP, modified FOLFIRINOX: mFFX. 


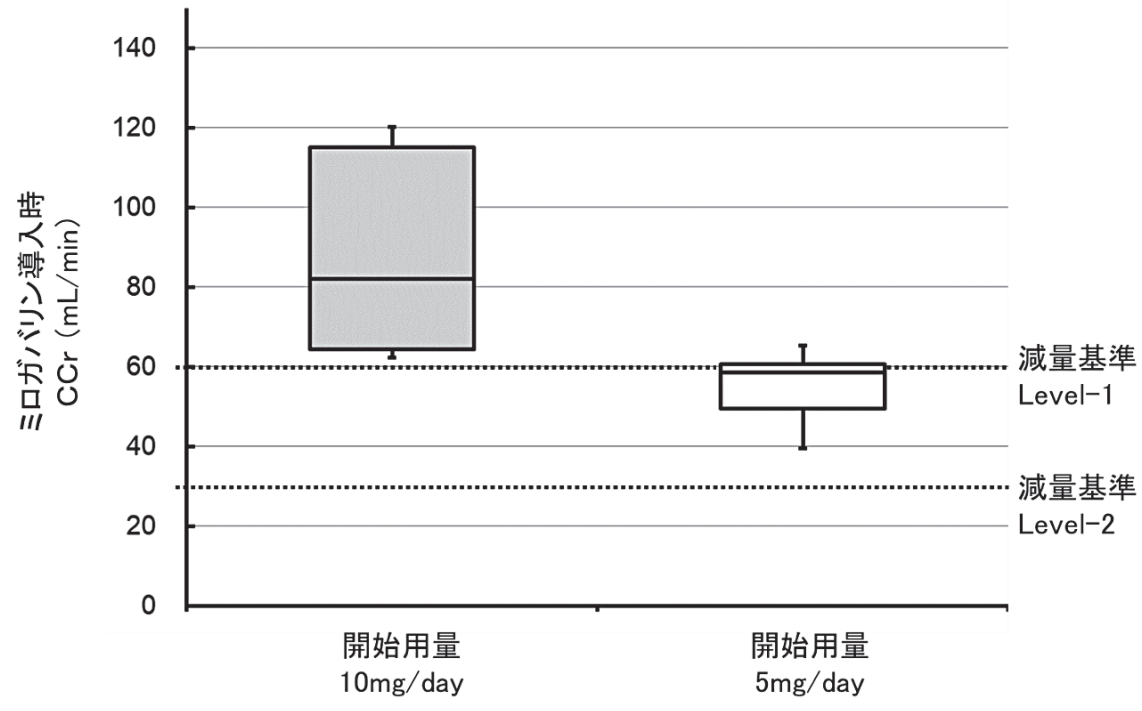

図 1 腎機能集団別ミロガバリン投与量

各箱ひげ図のラインは下から, 最小值, 第一四分位数, 中央值, 第三四分位数, 最大值を順に示す. ミロガバリンの初期用量は, $\mathrm{CCr} \geqq 60$ で $10 \mathrm{mg} / \mathrm{day}, 30 \leqq \mathrm{CCr}<60$ では $5 \mathrm{mg} / \mathrm{day}, \mathrm{CCr}<30$ は 2.5 mg/day である. また，点線はその CCrの減量基準值である．CCr: Creatinine clearance.

A

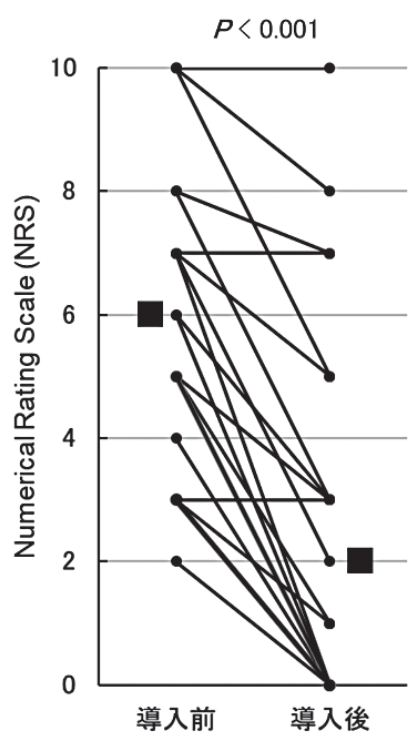

B

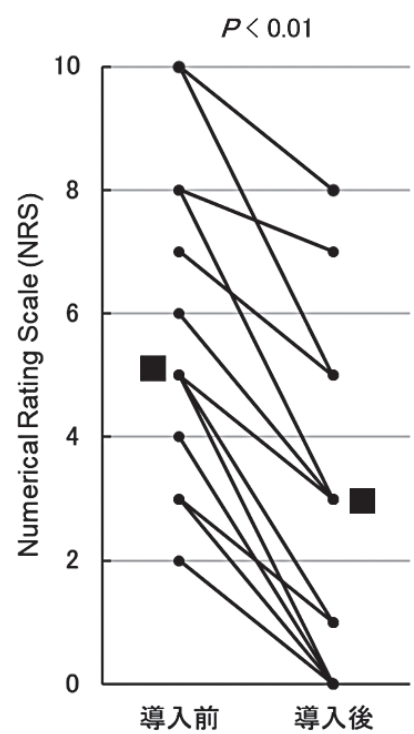

C

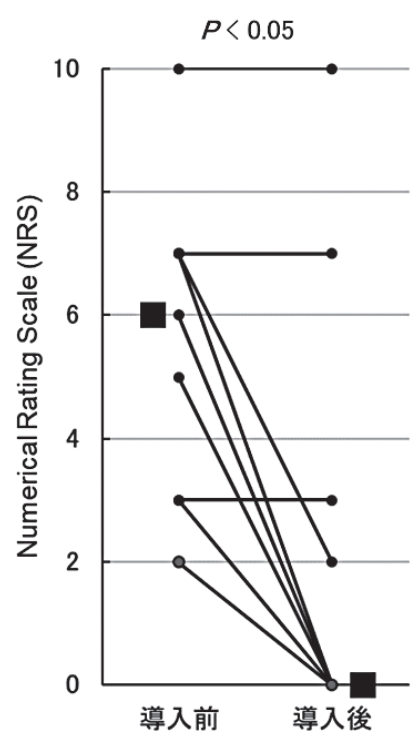

図 2 ミロガバリン導入前後の NRS 変化

A は全症例， B は夕キサン系抗がん薬，C はプラチナ系抗がん薬群の変化をそれぞれ示す．

は症例各々の NRS を 示す. ロはNRS 中央值を示す. 検定はウィルコクソン符号付順位和検定. NRS: numerical rating scale.

は，中央值 2 であった。 $(P<0.001)$ ，最良効果が 得られた時のミロガバリンの投与量を表 2 に示 す。NRS が改善した患者 18 名のうち，6名の患 者が初期用量で最良効果が得られた。その他の内 訳としては, 有効最低用量（1 段階増量）が 8 名, 有効推奨用量（2段階増量）が 4 名でそれぞれ最 良効果が得られた。ミロガバリン投与により追跡
期間内に NRS の改善が得られなかった患者は 3 名いたが，全員がプラチナ系抗がん薬含有レジメ ンで治療を受けていた。

症例 7 はミロガバリン導入 14 日目に初期投与 量で改善が得られず，原疾患による全身状態の悪 化で転院となり，追跡不能だった。症例 16 は, ミロガバリン導入 14 日後に有効最低用量に増量 
表 3 ミロガバリン投与全症例における副作用発現頻度

\begin{tabular}{lcc}
\hline \hline & $\leqq$ Grade 1-2 & $\geqq$ Grade 3 \\
\hline 傾眠 & $4(19 \%)$ & $0(0 \%)$ \\
四肢浮腫 & $4(19 \%)$ & $1(5 \%)$ \\
\hline
\end{tabular}

值は人数（\%割合）を示す. Grade 評価は, Common terminology criteria for adverse events version 5.0（CTCAE ver.5）に基づく.

したものの，改善が得られず，原疾患による状態 悪化のため，追跡ができなかった。症例 17 は， ミロガバリン導入 14 日後に有効最低用量まで増 量したものの，改善が得られなかった．この症例 に関しては，緩和医療の一環としてモルヒネやデ キサメタゾン，ロラゼパムなども同時に併用して おり，浮腫や傾眠があったため，ミロガバリンの 増量はなかった。

\section{3. 薬凨別 CIPN に対するミロガバリンの有効性}

図 2B およびC は，ミロガバリン投与による NRS の変化をその導入前後で，患者をタキサン系抗が ん薬群とプラチナ系抗がん薬群で分けて解析した 結果である. タキサン系抗がん薬群では導入前と 導入後の NRS 中央值はそれぞれ 5 および 3 だった $(P<0.01)$. 一方, プラチナ系抗がん薬群では, 導 入前と導入後の NRS 中央值はそれぞれ 6 および 0 だった $(P<0.05)$.

\section{CIPN に対するミロガバリン投与の安全性}

ミロガバリン投与患者 21 名における副作用発 現者数および発現率を表 3 に示す。傾眠 Grade 2 以下の発現は 4 名（19％）だった。四肢浮腫 Grade 2 以下の発現は 4 名 (19\%), Grade 3 が 1 名（5\%）で発現した。四肢浮腫 Grade 3 の患者 に関しては，この副作用のため，ミロガバリンが 中止となった。

\section{考察}

CIPN はその感覚異常から, 時に日常生活に支 障をきたし，回復に要する期間も月単位や年単位 の時間を要する，患者の生活の質が低下すること

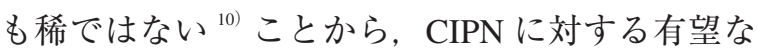
支持薬が望まれている。 今回, 本研究の結果から, ミロガバリンがタキサン系やプラチナ系抗がん薬
によるCIPNに対して有効である可能性が示唆さ れた，その臨床的意義としては，支持薬のエビデ ンスがそしいCIPN 領域において, 極めて重要な 知見が得られたことだと考える. 表 2 から, 対象 患者のなかには CIPN に対してミロガバリン以外 の支持薬を併用していた患者がいた，しかし，併 用薬はミロガバリン処方開始時点から使用されて おり，追跡期間中に増量されていないため, CIPN に対するミロガバリンの評価への影響は少ないと 考える。

図 2 より，ミロガバリンは夕キサン系やプラチ ナ系抗がん薬による CIPN に対するNRS を統計 学的有意に改善させた。一方, 表 1 の患者背景に 記載した通り, 本研究では対象レジメンに GNP 療法や modified FOLFIRINOX 療法（mFFX 療法） が多かった。これらのレジメンは, 膵臟がんにお ける国内ガイドライン ${ }^{23)}$ で, 局所進行あるいは 転移性病変の 1 次治療として, 推奨されているた め, CIPNの出現が多く予想される膵臟がん領域 においてミロガバリンの効果が期待される.

国内外の CIPN に関するガイドラインで唯一推 奨されている薬劑にデュロキセチンがある. Smith らは，オキサリプラチンおよびタキサン系 抗がん薬投与終了後に CIPN を認めている患者を 対象にして，プラセボ対照の無作為化二重盲検化 比較試験を行い, デュロキセチンの CIPN に対す る効果を検討している. ${ }^{13)}$ 試験開始 5 週後, デュ ロキセチン群において NRS の改善が 1.06 見られ, プラセボ群の 0.34 に対してその改善度合いは統 計学的に有意であった。しかし，層別化解析を実 施するとその効果はオキサリプラチンに限定的 で，タキサン系抗がん薬では有意差が見られな かった。一方, 我々が図 2B 拈よびCで薬効別に 調查した結果，プラチナ系扮よびタキサン系抗が ん薬の両群でミロガバリンの CIPN の改善が統計 学的有意差をもって見られた。 また，図2Bから， 夕キサン系抗がん薬群では全症例で NRS の改善 が見られ，ミロガバリンは特にタキサン系抗がん 薬群による CIPN に有効な可能性が示唆される. 一方, 図 2Cでプラチナ系抗がん薬群では無効 だった症例が 3 名いた。この理由としては，プラ チナ系抗がん薬の CIPN 発生機序が神経細胞体障 
害であるので, タキサン系抗がん薬による CIPN と比較して，回復に時間がかかる ${ }^{7)}$ ただと考え る. Hirayama らは，日本人の CIPN に対するデュ ロキセチンの効果を, ビタミン $\mathrm{B}_{12}$ 投与群を対照 とし, 無作為化のオープンラベル試験として検証 している. ${ }^{14)}$ 同試験の CIPN 起因薬剤として, パ クリタキセル，オキサリプラチン，ビンクリスチ ン，ボルテゾミブを visual analogue scale (VAS) を用いて検証している。結果は試験開始 4 週後, VAS でビタミン $\mathrm{B}_{12}$ 群の 0.2 の改善に対し, デュ ロキセチン群では 2.7 の改善を示し, デュロキセ チンの CIPN に対する効果が統計学的に示され た。しかし，デュロキセチンは神経障害性疼痛に 対しては保険適応に問題がある。一方, 本研究で 保険適応のあるミロガバリンが CIPN に対して有 効性が示唆されたことは重要である.

ミロガバリン添付文書 (タリージェ ${ }^{\circledR}$ 添付文書, 第一三共株式会社，2020 年 3 月改定第 4 版）の 重要な基本的注意の項や $5 \%$ 以上の発現頻度で出 現する副作用の項に傾眠と浮腫の記載があるた め, 今回は代表的な副作用である傾眠と浮腫の 2 つに関して調査を行った。本研究では, ミロガバ リン投与患者 21 名に打ける副作用の発現率とし ては，傾眠 Grade 2 以下が 19\%，四肢浮腫 Grade 2 以下が $19 \%$, Grade 3 が $5 \%$ だった。ミロガバ リンの類薬のプレガバリンも神経障害性疼痛に対 して保険適応であるが，その副作用として添付文 書（リリカ『添付文書，ファイザー株式会社，2019 年 11 月改定第 11 版）記載の糖尿病性抹消神経障 害に伴う疼痛におけるプレガバリンの国内長期投 与試験では, 傾眠, めまいや体重増加が $20 \%$ 以上 の発現率であった。 さらに同試験では, 副作用に よる内服中止が約 10\%生じている．実臨床でもプ レガバリンの安全性と副作用のリスク因子を検討

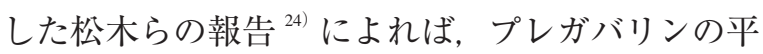
均投与量は, 副作用群で $125 \pm 76 \mathrm{mg}$, 非副作用 群でも $149 \pm 112 \mathrm{mg}$ であった. プレガバリンの維 持量が $300 \mathrm{mg}$, 最高投与量が $600 \mathrm{mg}$ であること を考えれば，十分に増量できていないことがわか る.これらの報告は直接比較されたものでないた め推察ではあるが, ミロガバリンはプレガバリン に比べて臨床上安全性が高い可能性がある.
Domon らの報告 ${ }^{20)}$ では, 薬理学的に, 電位依 存性カルシウムチャネル $\alpha_{2} \delta$ サブユニットには, $\alpha_{2} \delta-1$ と $\alpha_{2} \delta-2$ の 2 つサブタイプが存在する. $\alpha_{2} \delta-1$ は鎮痛作用に関与する一方， $\alpha_{2} \delta-2$ は中枢神 経抑制作用に関与する。 ミロガバリンとプレガバ リンは，いずれも $\alpha_{2} \delta$ サブユニットに対するリガ ンドであるが，ヒト in vitro の研究において，サ ブタイプによって異なる親和性を示す．ミロガバ リンはその解離半減期が， $\alpha_{2} \delta$ - 1 で 11.1 時間なの に対して， $\alpha_{2} \delta-2$ では 2.4 時間である。一方，プ レガバリンは $\alpha_{2} \delta-1, \alpha_{2} \delta-2$ のいずれに対しても 1.4 時間である。ささらに，先に記載の添付文書を参考 に生物学的半減期 (単回投与) を比べると, ミロ ガバリンが約 3 時間であるのに対し，プレガバリ ンは約 6 時間であるため, ミロガバリンは, プレ ガバリンよりも $\alpha_{2} \delta-1$ に選択的かつ持続的に結合 し, 血中から速やかに消失するために, 鎮痛効果 が持続的に得られ，中枢抑制から生じる傾眠やめ まいなどの副作用から回避しやすいと想定できる.

ミロガバリンの効果が得られた理由として, 薬 剂師による導入時の腎機能評価も有効であったと 考える. ミロガバリン導入時に $\mathrm{CCr}$ 評価がなされ ず, 過量で開始になった場合, 副作用が少ない薬 剂であっても，傾眠やふらつきなどの副作用で服 用中止になる可能性がある. 本研究では, ミロガ バリン導入時に全例で薬片師が $\mathrm{CCr}$ を算出し, 適 正な投与量の確認を行った結果, 図 1 にて各腎機 能集団で適正量のミロガバリンが投与された.

本研究の限界として, 評価対象を薬郕師がミロ ガバリンの新規導入当日から追跡開始できた患者 のみとしている点が挙げられる. また, 調查対象 のレジメン症例数にも偏りがあるため, 今後はよ り多数の患者拈よび多種類のレジメンでミロガバ リンの有効性を各々評価していく必要があると考 える. また, NRS の問診時期に関して定期ポイン 卜を定めていないため, 最良効果判定日はミロガ バリンが効果を発現するに至る日数の目安である と考える。

以上より, 本研究からミロガバリンは CIPN の 緩和効果があると示唆され, CIPN を生じる抗が ん薬治療における重要な支持薬の1つとなり得る と考える. また, 同時に薬剤師がミロガバリンの 
使用時における腎機能評価を行うことで，患者が 化学療法やミロガバリンの薬効を最大限に享受で き得ると考察する.

\section{利益相反}

開示すべき利益相反はない.

\section{引用文献}

1) Ishikawa K, Ogura M, Hamaguchi M, Hotta T, Ohnishi K, Sakai T, Sakamaki H, Yokoyama H, Harigae H, Morishima Y, Safety and Efficacy of Rasburicase (SR29142) in a Japanese phase II study, Cancer Sci, 2009, 100, 357-362.

2) Mizukami N, Yamauchi M, Koike K, Watanabe A, Ichihara K, Masumori N, Yamakage M, Olanzapine for the prevention of chemotherapy-induced nausea and vomiting in patients receiving highly or moderately emetogenic chemotherapy: a randomized, double-blind, placebo-controlled study, J Pain Symptom Manage, 2014, 47, 542-550.

3) Kosaka Y, Rai Y, Masuda N, Takano T, Saeki T, Nakamura S, Shimazaki R, Ito Y, Tokuda Y, Tamura K, Phase III placebo-controlled, double-blind, randomized trial of pegfilgrastim to reduce the risk of febrile neutropenia in breast cancer patients receiving docetaxel/cyclophosphamide chemotherapy, Support Care Cancer, 2015, 23, 1137-1143.

4) Schneider BP, Zhao F, Wang M, Stearns V, Martino S, Jones V, Perez EA, Saphner T, Wolff AC, Sledge GW Jr, Wood WC, Davidson NE, Sparano JA, Neuropathy is not associated with clinical outcomes in patients receiving adjuvant taxane-containing therapy for operable breast cancer, J Clin Oncol, 2012, 30, 3051-3057.

5）山本奈歩, 堀 祐貴, 高廣理佳子, 菅 幸生, 嶋田 努, 崔 吉道,アルブミン懸濁型パクリタキセル +ゲムシタビン療法における末梢神経障害リスク 因子に関する検討, 医療薬学, 2019, 45, 127-134.

6) Deloach LJ, Higgins MS, Caplan AB, Stiff JL, The visual analog scale in the immediate postoperative period: intrasubject variability and correlation with a numeric scale, Anesth Analg, 1998, 86, 102-106.

7）河野 豊, 永田博司, 末梢神経障害の機序, 日本 内科学会雑誌, 2017, 96, 1585-1590.

8）荒川和彦，鳥越一宏, 蓦巻直子, 鈴木 勉, 成田
年, 抗がん剂による末梢神経障害の特徴とその 作用機序, 日本緩和医療薬学雑誌, 2011, 4, 1-13.

9) Seidman AD, Berry D, Cirrincione C, Harris L, Muss H, Marcom MP, Gipson G, Burstein H, Lake D, Shapiro CL, Ungaro P, Norton L, Winer E, Hudis C, Randomized phase III trial of weekly compared with every-3-weeks paclitaxel for metastatic breast cancer, with trastuzumab for all HER-2 overexpressors and random assignment to trastuzumab or not in HER-2 nonoverexpressors: final results of cancer and leukemia group B protocol 9840, J Clin Oncol, 2008, 26, 1642-1649.

10) Argyriou AA, Polychronopoulos P, Iconomou G, Chroni E, Kalofonos, A review on oxaliplatininduced peripheral nerve damage, Cancer Treat Rev, 2008, 34, 368-377.

11) Hershman DL, Lacchetti C, Dworkin RH, Lavoie Smith EM, Bleeker J, Cavaletti G, Chauhan C, Gavin P, Lavino A, Lustberg MB, Paice J, Schneider B, Smith ML, Smith T, Terstriep S, WagnerJohnston N, Bak K, Loprinzi CL, Prevention and management of chemotherapy-induced peripheral neuropathy in survivors of adult cancers: american society of clinical oncology practice guideline, J Clin Oncol, 2014, 32, 1941-1967.

12）日本がんサポーティブケア学会編, “がん薬物療 法に伴う末梢神経障害マネジメントの手引き”, 2017年版, 金原出版, 東京, 2017, pp40-42.

13) Lavoie Smith EM, Pang H, Cirrincinoe C, Fleishman S, Paskett ED, Ahles T, Bressler LR, Fadul CE, Knox C, Le-Lindqwister N, Gilman PB, Shapiro CL, Effect of duloxetine on pain, function, and quality of life among patients with chemotherapy-induced painful peripheral neuropathy: a randomized clinical trial, JAMA, 2013, 309, 1359-1367.

14) Hirayama $Y$, Ishitani $K$, Sato $Y$, Iyama $S$, Takada $K$, Murase K, Kuroda H, Nagamachi Y, Konuma Y, Fujimi A, Sagawa T, Ono K, Horiguchi H, Terui T, Koike K, Kusakabe T, Sato T, Takimoto R, Kobune $\mathrm{M}$, Kato J, Effect of duloxetine in Japanese patients with chemotherapy-induced peripheral neuropathy: a pilot randomized trial, Int J Clin Oncol, 2015, 20, 866-871.

15) Atreya S, Pregabalin in chemotherapy induced neuropathic pain, Indian J Palliat Care, 2016, 22, 101103.

16) Oki E, Emi Y, Kojima H, Higashijima J, Kato 
T, Miyake Y, Kon M, Ogata Y, Takahashi K, Ishida H, Saeki H, Sakaguchi Y, Yamanaka T, Kono T, Tomita N, Baba H, Shirabe K, Kakeji Y, Maehara Y, Preventive effect of goshajinkigan on peripheral neurotoxicity of FOLFOX therapy (GENIUS trial): a placebo-controlled, double-blind, randomized phase III study, Int J Clin Oncol, 2015, 20, 765-775.

17）有生明雄, 高木昭佳, 須佐 充, 富山 徹, 高田 清和, 穴田栄一郎, 三村泰彦, 足立伊佐雄, mFOLFOX6 療法における末梢神経障害に対する药薬甘草湯 の有効性の検討, 日本病院薬剂師会雑誌, 2011, 47, 539-542.

18) Yamamoto K, Hoshiai H, Noda K, Effects of shakuyakukanzo-to on muscle pain from combination chemotherapy with paclitaxel and carboplatin, Gynecol Oncol, 2001, 81, 333-334.

19）日高隆雄, がん薬物治療の副作用軽減を目的と した漢方治療7タキサン系薬刻, 薬局, 2011, 62, 3514-3518.

20) Domon $Y$, Arakawa N, Inoue T, Matsuda F, Takahashi M, Yamamura N, Kai K, Kitano Y, Binding charac- teristics and analgesic effects of mirogabalin, a novel ligand for the $\alpha 2 \delta$ subunit of voltage-gated calcium channels, J Pharmacol Exp Ther, 2018, 365, 573582.

21) Baba M, Matsui N, Kuroha M, Wasaki Y, Ohwada S, Mirogabalin for the treatment of diabetic peripheral neuropathic pain: a randomized, double-blind, placebo-controlled phase III study in Asian patients, J Diabetes Investig, 2019, 10, 1299-1306.

22) Kato J, Matsui N, Kakehi Y, Murayama E, Ohwada S, Sugihara M, Mirogabalin for the management of postherpetic neuralgia: a randomized, double-blind, placebo-controlled phase 3 study in Asian patients, Pain, 2019, 160, 1175-1185.

23）日本膵臓学会脺癌診療ガイドライン改訂委員会 編, “膵癌診療ガイドライン”, 2019年版, 金原出 版, 東京, 2019, pp203-226.

24）松木悠佳, 石本雅幸, 塩浜恭子, 溝上真樹, 重見 研司，プレガバリン内服に伴う副作用発生と危 険因子の検討, 日本ペインクリニック学会誌, 2015, 22, 123-126. 